\title{
Guest Editorial: Business, Human Rights and Security
}

\begin{abstract}
All too often the business and human rights discourse, with its focus on addressing the abuses of corporations and other business enterprises, fails to adequately consider the precariousness of many people's daily existence and working environments. 'Security', in the sense of freedom from violence or the threat of violence, may well be in short supply in fragile situations where business enterprises operate. In these situations, threats of insecurity may take the form of intimidation, conflict and violence, as business interests clash with those of individuals and groups. At the same time, the often unstable context in which business activities take place may attract various public and private security actors, armed groups and criminal gangs, some working directly for businesses, others taking advantage of the unstable situation. Paradoxically, what is often seen as the resulting securitization ${ }^{1}$ of business activities may actually contribute to increased violence and insecurity as those actors pursue divergent agendas.
\end{abstract}

\section{BACKGROUND}

This special issue explores the relationship between business, human rights and security. It brings into sharper focus various forms of insecurity in the business environment that impact on the full enjoyment of fundamental human rights. In so doing, it aims to increase our understanding of the wider impacts of business and security actors on human rights, the relationship between them, and the right to security of the individual person as well as local and indigenous communities. Those impacts are not limited to certain economic sectors, such as textiles/apparel, information technology or the extractive industries, which may be bound up with supply chains. Instead, they embrace all sectors of the economy, either locally or globally.

While states still bear the primary obligation under international law to protect individuals, communities or groups from human rights abuses committed by transnational corporations (TNCs), small and medium-sized enterprises (SMEs), private military and security companies (PMSCs) and other business enterprises, such companies, corporations and enterprises also have a responsibility to respect human rights. According to the United Nations Guiding Principles on Business and Human Rights (UNGPs), ${ }^{2}$ corporations and other business enterprises have a responsibility to respect human rights. It means that they should avoid infringing on the human rights of others and address adverse human rights impacts with which they are involved. ${ }^{3}$

1 The term 'securitization' means 'security-affected' business activities. It does not refer to the financial practice of pooling various types of assets or contractual debt, which are re-packaged into interest-bearing securities.

2 Human Rights Council, 'Guiding Principles on Business and Human Rights: Implementing the United Nations "Protect, Respect and Remedy" Framework', A/HRC/17/31 (21 March 2011).

3 Ibid, Guiding Principle 11. 
At the same time states face greater scrutiny of activities with respect to businessrelated human rights abuses, which are linked to the physical and psychological security of individuals, groups and communities. In particular, where such abuses have been facilitated by the state, acting severally or jointly with private actors, or the state has failed to exercise due diligence in responding to violence by private actors, including private security providers, the role of armed forces personnel, police forces, and paramilitaries has to be critically re-evaluated. Even if state forces are not directly involved in violence and human rights abuse, there may be issues of complicity, or of failing to take reasonable measures, against militias, criminal gangs, private security actors and corporate security personnel, raising issues of state responsibility and/or joint responsibility.

A specific nexus between business, human rights and security exists in conflict-affected and high-risk areas where certain political, economic and social conditions prevail. In the case of such areas, business operations may exist independently of violent conflict but nevertheless conflict affects those operations, or there may be conflict between a company and the neighbouring community. Likewise, business activities in conflict-affected and high-risk areas may increase the risks of enterprises fuelling conflict, contributing to, or facilitating, human rights abuses committed by other actors, such as security forces or armed non-state actors. The UNGPs recognise the heightened risk that such business activities raise and urge states to help ensure that business enterprises operating in those contexts are not involved with such abuses. ${ }^{4}$ Furthermore, in the business, human rights and security context, individuals, communities and groups, whose rights are affected by business activities, may be unable to obtain meaningful redress at the local, national or international level. Or else they fear retaliation in their attempts to seek remedial action. The added element of a situation of insecurity, which may arise from acts of intimidation, conflict or violence in their working environments, may render any remedial action futile. Additionally, access to justice for some victims of business and security-related human rights abuses may remain illusory either because there is a lack of remedy, or else due to the prohibitive or restrictive procedural means of effectuating such remedy.

\section{Overview of Contributions}

This special issue contains five peer-reviewed articles that focus on the relationship between business, human rights and security. In the initial contribution, Maryah Farah and Maha Abdallah discuss the paradox arising from the increased securitization of business activities in the Occupied Palestinian Territories (OPT). They argue that Israel's prolonged occupation of Palestinian territory and its booming 'security' industry provoke genuine questions about the status and implementation of international law, and the role of and opportunity for third states and businesses actors to influence developments. In turn this gives rise to thorny issues of corporate accountability and state responsibility for the activities of foreign business operators in the OPT. The authors argue that in this respect civil society has an important role to play in advancing the business and human rights framework to hold such actors to account, illustrating how

\footnotetext{
4 Ibid, Guiding Principle 7.
} 
the UNGPs can provide traction even within a heavily securitized and politicized environment.

The common thread that runs through the next three contributions is the involvement of PMSCs - more often known as private security companies (PSCs) - that may perpetrate human rights abuses in the ordinary course of their business activities, occasionally aided and abetted by states. The second article is by Daria Davitti who examines the rise of PMSC activity in the delivery of European Union (EU) migration control policies. She argues that PMSCs not only provide border security and migration control services but also frame, shape and entrench militarized responses within the European Migration Agenda. The context in which PMSCs conduct such operations fulfils the conditions of 'high-risk' operations for the purpose of applying the UNGPs, absent an actual armed conflict, ${ }^{5}$ whenever there is a risk of their involvement in gross human rights abuses. A re-definition of the refugee 'crisis' as a high-risk context would enable identification of the heightened human rights obligations of home states and the corporate responsibility of PMSCs in undertaking migration control measures, as part of the EU's Common Security and Defence Policy. ${ }^{6}$ The article by Daria Davitti, along with the previous article on the OPT by Maryah Farah and Maha Abdallah, suggest that the UNGPs may be able to perform a constitutive role in areas beyond the territory of states, whether in occupied land or in migration control.

Sorcha MacLeod and Rebecca DeWinter-Schmitt offer a critical analysis of the extent to which auditing and certification to quality assurance and risk management standards, containing human rights-related requirements, are an adequate and effective means of ensuring that PSCs meet their responsibility to respect human rights. Applying constructivist theory, they test the promise of third party auditable management systems, like ANSI/ASIS PSC. $1^{7}$ and ISO $18788,{ }^{8}$ to operationalize into business practice standards the human rights and humanitarian principles at the heart of the International Code of Conduct (ICoC), ${ }^{9}$ which builds on the UNGPs. Their analysis reveals manifest weaknesses in the process of certifying human rights adherence through such quality assurance and risk management standards, and associated processes. These need to be addressed by both national and private standard accreditation bodies as well as the PSC industry at large.

The ICoCA, ${ }^{10}$ which is charged with overseeing and monitoring members' adhesion to the ICoC, could play a significant role in this respect. The article provides a clear warning that care is needed to ensure that codes of conduct that purport to build on the principles contained in the UNGPs, and which look to be taking those principles so much further, do not, in fact, weaken the universality of the UNGPs. It must be borne in mind

\footnotetext{
5 On the basis of Guiding Principles 7 and Guiding Principle 23(c), ibid.

6 For details of the EU's Common Security and Defence Policy, see: https://eeas.europa.eu/topics/common-securityand-defence-policy-csdp_en.

7 ANSI/ASIS PSC.1-2012 is a management standard for quality of private security company operations, developed by the American National Standards Institute (ANSI)/American Society for Industrial Security (ASIS) Private Security Company (PSC), series 1 (2012).

8 International Standards Organization (ISO) Management System 18788 (2015).

9 International Code of Conduct for Private Security Service Providers (ICoC) was signed on 9 November 2010 by 58 companies; as of September 2013, 708 companies had formally committed to operate in accordance with the ICoC.

10 International Code of Conduct Association (ICoCA), established in Geneva, Switzerland.
} 
that the Code of Conduct was drafted, and is largely being enforced, by a self-selecting group of states and businesses. Nevertheless, if the Code can be more widely implemented and enforced, with buy-ins from a wider group of states and businesses, it has the potential to deliver on the values underpinning the UNGPs as the next article shows.

The fourth article by Christina Narváez González and Katharine Valencia takes up the challenge of investigating the role of the PSC industry in Latin America, which has been associated with human rights abuses, particularly in the context of extractives. Very little has been written on the Latin American experience with PMSCs or PSCs. The examination of PSCs in the article is based on case studies in Honduras, Peru and Guatemala, variously involving indigenous and local communities in land disputes with agribusiness operators, excessive use of force by PSCs and police operations in mining operations, and, in the case of Colombia, paramilitary activities in both sectors. From their research, the authors maintain that there needs to be better control and monitoring of PSCs and other actors, in particular where there is a blurring of the lines between public and private authority in the securitization and policing of such business activities for human rights abuses. To this end, they argue that the adoption of the ICoC by more Latin American PSCs, as well as the involvement of regional governments and civil society in the work of ICoCA, could help to strengthen respect for and protection of human rights and business in the region.

The final contribution to the special issue is an extended comment by Núria Reguart Segarra on business, human rights and security in the recent case law of the InterAmerican Court of Human Rights (IACtHR). ${ }^{11}$ In her contribution, she examines the land grabbing activities of major corporations in the agribusiness sector in Latin America, which infringe upon the property rights and threaten the personal security of indigenous peoples, such as the Kichwa people of Sarayaku in the Ecuadorian Amazon region, the Garifuna communities in Honduras and the Yakye Axa, Sawhoyamastra and Xákmok Kásek communities in Paraguay. It is an important reminder of the obligation a state has to ensure respect for human rights by business enterprises, as outlined in the UNGPs.

Indigenous people are affected by business activities in terms of their livelihoods, ways of life, rights and security. There is the question of the responsibility of businesses for rights violations against indigenous communities when protecting their interests through or with the assistance of security actors. The issue of state involvement is then raised, with instances of law enforcement agencies turning a blind eye to such incursions, even sometimes involving the military in business, thereby increasing the peoples' insecurity.

The article raises the question as to what measures the state should take; for example, does it include positive obligations to ensure that its security forces actively police such situations?; or that any private security contractors working for businesses comply with a rigorous licensing system? The article also shows instances where the state has used its security forces to undermine the security of indigenous peoples, not to strengthen it.

11 Inter-American Court of Human Rights (IACtHR) commenced operations on 22 May 1979, with its Statute being formally adopted by the Organization of American States (OAS) at its Ninth Regular Session, held in La Paz Bolivia, October 1979 (Resolution No. 448). 
Through a careful exposition of the uneven and limited protections provided by the IACtHR, the article helps us start to develop an understanding of the link between the insecurity of peoples and the human rights protection that the state should provide. A concern not to overburden the state must be balanced against the undoubted obligations that it has to both protect and ensure respect for human rights in the context of business activities.

Together these articles examine the intersection between business, security and human rights in the light of three factors: the inevitable expansion of business into increasingly fragile and often contested spaces; the accompanying securitization of those spaces, with a focus on the security of businesses and not necessarily of individuals or groups living in them; and the increasing recognition that such trends require greater national and international regulation in order to protect the rights of the individual from the combined effects of business and security. However, these articles show that improved regulation needs to be so much more than the adoption of principles, codes and rules, important though they may be as starting points. The move must now be towards ensuring compliance by business and security actors with human rights standards, through court judgments but also through non-judicial means of accountability and access to justice. This collection makes a promising start in that regard, and invites further discussion and research.

Mary E. FOOTER

Professor of International Economic Law

Nigel D. WHITE

Professor of Public International Law;

co-Directors, Nottingham International Law and Security Centre (NILSC),

University of Nottingham School of Law, UK 